\title{
A Prática do Mandado de Segurança
}

$\mathrm{O}$

mandado de segurança é uma das peças mais importantes da engrenagem de contrôle jurisdicional dos atos administrativos. A lei, ao instituí-1o, procurou cercá-lo de meios que assegurem o pronto restabelecimento do direito líquido e certo, nos casos de violação por ato ilegal da autoridade. Sem isso talvez êle se tornasse inoperante ou, pelo menos, seu rendimento deixasse de corresponder aos objetivos sociais em vista.

Mas as precauções da lei, visando ao rápido andamento dos mandados de segurança, têm sido, com alarmante freqüência, fonte de grandes transtornos para o Serviço Público. É comum ouvir-se dizer que o juiz, ao apreciar os pedidos de mandados dessa espécie, age sob os efeitos psicológicos que the advêm do conhecimento do espírito da lei, que êle sabe ter sido feita para proteger o particular e garantir a êste último a pronta reparação do direito ofendido. $E$ que isso o leva, muita vez insensivelmente, a predispor-se contra a administração; a aceitar com excessiva ligeireza as alegações tendenciosas dos particulares; a usurpar o papel do legislador, dando aos textos legais uma interpretação que, pela sua demasiada liberalidade, amplia favores e cria direitos; a invadir a esfera de competência do Poder Executivo e seus agentes, mesmo em matéria de natureza nitidamente discricionária.

É possivel que reparos como êsses encerrem boa parcela de verdade; é possível, ainda, que os efeitos psicológicos acima citados e sua daninha floração de julgados prejudiciais ao interêsse coletivo assinalem, apenas, um estágio passageiro no processo de amadurecimento do mandado de segurança e que em relação a êste último se venham a operar, pela ação do tempo, as mesmas depurações e ajustamentos por que passou o instituto do habeas-corpus.

É forçoso reconhecer, porém, que a responsabilidade pelos desvios que se têm verificado na prática do mandado de segurança cabe 
também aos legisladores, pela elaboração de leis dúbias, descuidadas, nas quais os institutos não encontram definição precisa e as condições para gôzo de favores são fixadas sem maiores cautelas; aos administradores mal esclarecidos, pela contumácia na prepotência e no desprêzo pelos direitos dos particulares; e, finalmente, à imensa côrte daqueles que, por deformação do espírito profissional ou imoderada cupidez, industrializam em proveito próprio os defeitos da lei.

Acometido por todos os lados, envolvido na teia de tantos fatôres que the dificultam o trabalho já de si extremamente delicado, o juiz, em tôrno de cuja decisão se concentram as atenções gerais, é o alvo preferido de tôdas as criticas.

O legislador, nesse particular, fica em situação privilegiada, pois as censuras em que acaso incorre são dirigidas a pessoa indeterminada, não atingem a um indivíduo certo. A sentença é ato individual, a que se vincula, diretamente, a pessoa do juiz. A lei é impessoal, no sentido de que não se pode atribuir a responsabilidade pela sua elaboração a um indivíduo determinado.

Também o particular se encontra em posição mais cômoda que a do juiz, porque nêle se toleram, com justificável benevolência, os erros e os equívocos na interpretação das leis, sobretudo quando estas oferecem margem para que êle delas extraia um entendimento favorável às suas pretensões. A simples possibilidade dêsse entendimento faz nascer para o particular, conforme princípio universalmente aceito, o interêsse legítimo, econômico ou moral, que é o pressuposto do exercício da demanda.

Nem por isso, entretanto, o legislador, o administrador e os particulares são menos responsáveis por uma situação que se costuma imputar, exclusivamente, ao magistrado.

Mas, como quer que se distribuam os quinhões de responsabilidade pelos malefícios de que nos dão notícia os registros forenses ciêstes últimos anos, alguma coisa tem de ser feita, para que a administração pública, não menos digna de proteção que os direitos dos particulares, seja poupada aos males que 1 he vem causando a prá¿ica abusiva do mandado de segurança.

O primeiro passo a dar consistiria, talvez, numa cuidadosa revisão da lei em vigor, com o estabelecimento de critérios objetivos 
para a conceituação de "direito líquido e certo"; com o exasperamento das sanções aplicáveis aos casos de desídia no cumprimento do dever de prestar a tempo, e de modo exato e completo, as informações solicitadas pela autoridade judiciária; com o estabelecimento de um sistema de cauções que assegurassem ao erário público a fácil reposição das quantias despendidas em virtude de sentenças suscetiveis de reforma na instância superior.

Certamente essas medidas não alcançariam tôdas as causas que precisariam ser erradicadas, mas já representariam um considerável progresso, ao qual o tempo, a paulatina melhoria das fórmulas e das práticas processuais, e o aperfeiçoamento da própria compreensão do mandado de segurança viriam a acrescentar novas conquistas. 